\title{
Effect of Gibberellic Acid on Growth and Seed Yield of Coriander (Coriandrum sativum L.)
}

\author{
Sachin Kumar", T.P. Malik and S.K. Tehlan \\ Department of Vegetable Science, CCS Haryana Agricultural University, Hisar, \\ Haryana-125001, India \\ *Corresponding author
}

\section{A B S T R A C T}

\section{Keywords \\ Coriander, \\ Gibberellic acid, \\ Yield, Seed soaking and $50 \%$ flowering \\ Article Info \\ Accepted: \\ 18 August 2018 \\ Available Online: \\ 10 September 2018}

The experiment was conducted to study the effect of gibberellic acid on growth and seed yield of coriander (Coriandrum Sativum L.) cv. Hisar Sugandh and Hisar Bhoomit. In the present experiment, gibberellic acid concentration $50 \mathrm{ppm}$ was used at three different stages of crop growth (seed soaking, spray at leaf stage and spray at $50 \%$ flowering). Gibberellic acid was sprayed in eight treatment combinations of three stages. Based on the experimental results, it was concluded that application of gibberellic acid improved the growth, yield of coriander seeds. Seed soaking + spray at leaf stage + spray at $50 \%$ flowering stage was the right combination for gibberellic acid application to improve the growth and yield of coriander. In case of spray at two stage, (seed soaking + spray at leaf stage) was the right combination to improve the biological yield, whereas, (spray at leaf stage + spray at $50 \%$ flowering) was the right combination to improve the seed yield. With the combination of Seed soaking + Spray at leaf stage + Spray at 50\% flowering, the variety Hisar Sugandh found better for seed yield.

\section{Introduction}

Seed spices are annual herbs, whose dried seeds or fruits are used as spices. They are nature's gift to humankind as they add flavour to our food. In addition, they also have preservative and medicinal values (Anonymous, 2015). Coriander seed have aromatic odour and taste of coriander fruits due to an essential oil, which is made up of hydrocarbon and oxygenated compounds. Besides the essential oil, the seed contain $16.1 \%$ fatty oil, $14.1 \%$ protein, $21.6 \%$ carbohydrate, $32.6 \%$ fibers, $11.2 \%$ moisture and $4.4 \%$ mineral matters and coriander leaves are rich source of vitamin A and Vitamin C (Singh et al., 2017) Plant growth regulators (PGRs), have emerged as magic chemical that could increase agricultural production at an unprecedented rate and help in removing or circumventing many of the barrier imposed by genetics and environment (Nickel, 1982). Effectiveness of PGRs depends upon several factors viz. concentration, methods and time of application, etc. As such different modes (seed soaking, foliar spray, soil application, stem injection, etc.) of application of PGRs alter the physiology of plant in different ways. It is well known that all the PGRs regulate the physiological functions/processes of the plant. 
Among different PGRs, NAA and $\mathrm{GA}_{3}$ has been reported to boost the growth, yield and quality attributes in coriander. Gibberellic acid is found to be one of the most important means to increase yield and seed quality in many of the seed spices like fenugreek, coriander and cumin. Keeping in view the above facts, the present experiment has been conducted to study the effect of $\mathrm{GA}^{3}$ on growth and seed yield of coriander.

\section{Materials and Methods}

The field experiment was conducted during Rabi season of 2016-17 at Research Farm of the Department of Vegetable Science, CCS Haryana Agricultural University, and Hisar.

The seed material used for the present investigation was varieties Hisar Sugandh and Hisar Bhoomit, which was procured from the Department of Vegetable Science, CCS Haryana Agricultural University, Hisar (Haryana). In the present experiment, one gibberellic acid concentration $(50 \mathrm{ppm})$ including control was used at three different stages of crop growth, Seed soaking ( $8 \mathrm{hrs}$.), spray at leaf stage and spray at $50 \%$ flowering stage.

Eight treatment combinations of one variety are laid out in Randomized Block Design were replicated thrice of both varieties making total of 48 plots. Need based cultural and plant protection operations were taken up to harvest. Ten plants from each replication were selected at random to record data on morphological aspects and yield attributing characters.

The harvest index was calculated by dividing the economic yield (seed yield per plot) with total biological yield and expressed as percentage (Donald and Hamblin, 1976). The experimental data was analyzed statistically by the method of analysis of variance as outlined by Panse and Sukhatme (1961).

\section{Experimental details}

Design: Randomized Block Design

Replications: Three

Treatment combinations: 16

Total plots: 48

Plot size: $3.0 \times 2.4 \mathrm{~m}$

Plant spacing: $30 \times 20 \mathrm{~cm}$

Date of sowing: $6^{\text {th }}$ Nov. 2016

\section{Stages of application}

Seed soaking ( $8 \mathrm{hrs}$.)

Spray at leaf stage

Spray at 50\% flowering stage

\section{Treatment combinations}

T1: Control (Water Spray)

T2: Seed soaking $\left(\mathrm{GA}_{3} @ 50 \mathrm{ppm}\right)$

T3: Spray at leaf stage $(30$ DAS $)$ (GA 3 @50ppm)

T4: Spray at $50 \%$ flowering stage $\left(\mathrm{GA}_{3} @ 50 \mathrm{ppm}\right)$

T5: Spray at leaf stage+ Spray at 50\% flowering stage $\left(\mathrm{GA}_{3} @ 50 \mathrm{ppm}\right)$

T6: Seed soaking+ Spray at leaf stage $\left(\mathrm{GA}_{3} @ 50 \mathrm{ppm}\right)$

T7: Seed soaking+ Spray at 50\% flowering stage $\left(\mathrm{GA}_{3} @ 50 \mathrm{ppm}\right)$

T8: Seed soaking+ Spray at leaf stage+ Spray at $50 \%$ flowering stage $\left(\mathrm{GA}_{3} @ 50 \mathrm{ppm}\right)$

\section{Plant height at 60 days, 90 days, 120 days and harvest}

The height of ten randomly tagged plants was recorded from ground level to the tip of main 
shoot at 60 DAS, 90 DAS, 120 DAS and at harvest, and was expressed in centimeters $(\mathrm{cm})$. The mean height of ten plants was worked out.

\section{Number of branches per plant at harvest}

The number of branches per plant was counted on ten randomly selected plants at harvest and the average number of branches per plant was calculated.

\section{Days to 50 per cent flowering}

The plants in each plot were observed for dates of flowering and dates of flowering on 50 per cent plants in each plot were recorded. Based on the date, days taken to 50 per cent flowering were worked out for each plot.

\section{Number of umbels per plant}

The total number of umbels in ten randomly selected plants in each plot was counted and the number of umbels per plant was calculated by averaging the value for each treatment.

\section{Number of umbellet per umbel}

The number of umbellets per umbel in ten randomly selected plants in each plot were counted and the number of umbellets per umbel were calculated by averaging the value for each treatment.

\section{Number of seeds per umbellet}

The number of seeds in all the umbellets in umbels of ten randomly selected plants from each treatment was counted and average number of seeds per umbellet was worked out.

\section{Number of seeds per umbel}

The number of seeds in umbels of randomly selected ten plants from each treatment was counted and later the values were averaged out.

\section{Biological yield (Kg/Plot)}

The total above ground biomass of all the plants, which were left in their respective plots after harvest for sun drying, was weighed and the values were expressed in $\mathrm{kg} /$ plot.

\section{Harvest index}

The harvest index was calculated by dividing the economic yield (seed yield per plot) with total biological yield and expressed as percentage (Donald and Hamblin, 1976).

Harvest index $=$ Economic yield $\mathrm{X}$ 100/Biological Yield.

\section{Seed yield (Kg/plot)}

Plants were harvested in each plot separately using sickle. The harvested plants were left in the field for few days to sundry the plants and later they were threshed. After cleaning, the weight of seeds $(\mathrm{kg} / \mathrm{plot})$ was recorded. The values were later converted to quintal per hectare.

\section{Results and Discussion}

In present investigation, the application of gibberellic acid showed considerable increase in plant height. The data present in Table 1. Indicate that all treatments differed significantly from each other with respect to plant height. The values for plant height at maturity ranged from $102.1 \mathrm{~cm}$ to $127.8 \mathrm{~cm}$ for both varieties. In present experiment, for both varieties, the treatment T8 (Seed soaking+ Spray at leaf stage+ Spray at 50\% flowering stage) showed maximum results with respect to plant height. Among both varieties, maximum height was attainted by Hisar Bhoomit at T8 measured at 60 days, 90 days, 
120 days and maturity. The increase in plant height as a result of gibberellic acid application might be due to the stimulation of cell elongation while increasing the plasticity of cell wall and rapid cell division in the growing portion leading to increased length of internodes (Mohammed, 1975). The results are in conformity with the findings of Haokip et al., (2016) and Singh et al., (2012) in coriander (Coriandrum sativum L.).

The data presented in Table 2. Indicate that the values for number of branches per plant varied from 7.3 to 9.2 for both varieties. Among different stages of application, T8 (Seed soaking+ Spray at leaf stage+ Spray at $50 \%$ flowering stage) resulted in maximum number of branches per plant for both the varieties. In both varieties (Hisar Sugandh and Hisar Bhoomit), maximum number of branches per plant was in Hisar Bhoomit at T8 (9.2). The increase in number of branches per plant might be due to the effect of the gibberellic acid which enhances the lateral buds, breaking apical dominance and vegetative growth. The results are in accordance with the findings of Meena et al., (2006), Verma and Sen (2006) in coriander.

The number of umbels per plant varied from32 to 48.7 for both varieties. Among various stages of application, T8 showed the best result with respect to number of umbels per plant in both varieties. Maximum number of umbels per plant attainted in Hisar Bhoomit at $\mathrm{T} 8$ (48.7).

The number of umbellets per umbel varied from 5.7 to 7.8. Among various stages of application, T8 showed the best result with respect to number of umbellet per umbel for both varieties. Maximum number of umbellets per umbel attainted in Hisar Bhoomit at T8 (7.8) and T6 (7.8). Improved vegetative growth due to gibberellic acid application coupled with increased photosynthesis on one hand and greater mobilization of photosynthates towards reproductive sites, on the other, might have increased the number of umbels per plant and umbellet per umbel. Haokip et al., (2016) also reported increase in number of umbels per plant and umbellet per umbel at 50 ppm of $\mathrm{GA}_{3}$ in coriander.

The days to $50 \%$ flowering varied from 79.3 to 118.Among different treatment applied on coriander, the treatment T6 (Seed soaking+ Spray at leaf stage) took minimum days to 50 per cent flowering. The minimum days to $50 \%$ flowering observed in Hisar Sugandh at T6 (79.3 days).

The application of gibberellic acid shortened the juvenile phase, and thus, induced early flowering and then early maturity in coriander. The data presented in Table 3. Indicated that among different treatment applied on coriander, the treatment $\mathrm{T} 8$ took minimum days to maturity and was found to advance maturity. Hisar Sugandh took minimum days to maturity at T8 (138.7) between two varieties. The results of the present study indicate gibberellic acid involvement in transition of vegetative apices to floral apices in coriander. The results of the present investigation are in accordance with the findings of Gour et al., (2009) and Panda et al., (2007).

The data presented in Table 3. indicated a considerable variation for number of seeds per umbellet, Total seed per umbel, Biological Yield (kg/plot), Seed yield (kg/plot), Seed yield (q/ha), Harvest Index (\%) in all treatments over control. For both varieties, T8 showed the maximum result with respect to number of seeds per umbellet and total seed per umbel. Hisar Bhoomit performed better for number of seeds per umbellet (7.6) and total seed per umbel (56.4). The results are in accordance with the findings of Prajapat et al., (2015). 
Table.1 Effect of gibberellic acid applied at different stages on plant height $(\mathrm{cm})$ in coriander varieties

\begin{tabular}{|c|c|c|c|c|c|c|c|c|}
\hline Treatments & \multicolumn{2}{|c|}{ 60DAS* } & \multicolumn{2}{|c|}{ 90DAS } & \multicolumn{2}{|c|}{ 120DAS } & \multicolumn{2}{|c|}{ Maturity } \\
\hline Variety & $\begin{array}{c}\text { Hisar } \\
\text { Sugandh }\end{array}$ & $\begin{array}{c}\text { Hisar } \\
\text { Bhoomit }\end{array}$ & $\begin{array}{c}\text { Hisar } \\
\text { Sugandh }\end{array}$ & $\begin{array}{c}\text { Hisar } \\
\text { Sugandh }\end{array}$ & $\begin{array}{c}\text { Hisar } \\
\text { Sugandh }\end{array}$ & $\begin{array}{c}\text { Hisar } \\
\text { Bhoomit }\end{array}$ & $\begin{array}{c}\text { Hisar } \\
\text { Sugandh }\end{array}$ & $\begin{array}{c}\text { Hisar } \\
\text { Bhoomit }\end{array}$ \\
\hline T1 & 42.1 & 43.8 & 76.1 & 78.7 & 88.6 & 91.7 & 102.1 & 103.6 \\
\hline $\mathrm{T} 2$ & 45.4 & 45.7 & 80.6 & 85.9 & 91.4 & 97.3 & 105.1 & 108.6 \\
\hline T3 & 50.3 & 51.1 & 86.3 & 90.9 & 97.4 & 102.9 & 109.5 & 112.5 \\
\hline $\mathrm{T} 4$ & 41.6 & 42.3 & 78.3 & 79.1 & 94.5 & 98.8 & 107.2 & 107.7 \\
\hline T5 & 49.7 & 53 & 83.4 & 93.6 & 106.1 & 111.1 & 117.3 & 123.3 \\
\hline T6 & 51.2 & 54.4 & 87.8 & 96.2 & 100.1 & 106.9 & 109.4 & 117.5 \\
\hline T7 & 44.4 & 46.6 & 81.8 & 88.3 & 105.7 & 108.6 & 115.6 & 119.8 \\
\hline T8 & 52.4 & 54.8 & 89.4 & 98.6 & 111 & 117.1 & 119.6 & 127.8 \\
\hline C.D. at 5\% & 5.5 & 6.3 & 5.3 & 10.2 & 6.9 & 10.5 & 5.9 & 9.4 \\
\hline
\end{tabular}


Table.2 Effect of gibberellic acid applied at different stages on Number of branches per plant, Number of umbel per plant, Number of umbellet per umbel at maturity and Day to $50 \%$ flowering in Coriander

\begin{tabular}{|c|c|c|c|c|c|c|c|c|}
\hline Treatments & \multicolumn{2}{|c|}{$\begin{array}{c}\text { Number of branches per } \\
\text { plant }\end{array}$} & \multicolumn{2}{|c|}{$\begin{array}{c}\text { Number of umbels per } \\
\text { plant }\end{array}$} & \multicolumn{2}{|c|}{$\begin{array}{c}\text { Number of umbellet per } \\
\text { umbel }\end{array}$} & \multicolumn{2}{|c|}{ Day to $50 \%$ flowering } \\
\hline $\mathbf{T 1}$ & 7.3 & 7.2 & 32 & 42.6 & 5.7 & 7 & 93.3 & 118 \\
\hline T3 & 8.6 & 8.6 & 41.4 & 46.9 & 6.9 & 7.6 & 82.3 & 108 \\
\hline $\mathrm{T4}$ & 7.7 & 7.9 & 34.7 & 44.1 & 6.5 & 7.4 & 94 & 119 \\
\hline T6 & 8.6 & 8.9 & 43.3 & 47.4 & 7.2 & 7.8 & 79.3 & 104 \\
\hline T7 & 8.1 & 8.2 & 38.7 & 45.6 & 6.7 & 7.5 & 84.6 & 115.3 \\
\hline $\mathrm{T8}$ & 8.8 & 9.2 & 45.7 & 48.7 & 7.3 & 7.8 & 81 & 105.3 \\
\hline C.D. at 5\% & 1 & 1.2 & 3.9 & 3.6 & 0.4 & 0.5 & 3.6 & 4.7 \\
\hline
\end{tabular}


Table.3 Effect of gibberellic acid applied at different stages on number of seeds per umbellet, number of seeds per umbel and days to maturity, biological yield, seed yield per plot, seed yield per hectare and harvest index in coriander

\begin{tabular}{|c|c|c|c|c|c|c|c|c|c|c|c|c|c|c|}
\hline \multirow[t]{2}{*}{ Treatments } & \multicolumn{2}{|c|}{$\begin{array}{l}\text { No. of seeds per } \\
\text { umbellet }\end{array}$} & \multicolumn{2}{|c|}{$\begin{array}{c}\text { Total seed per } \\
\text { umbel }\end{array}$} & \multicolumn{2}{|c|}{ Days to maturity } & \multicolumn{2}{|c|}{$\begin{array}{c}\text { Biological Yield } \\
\text { (kg/plot) } \\
\text { Yield (kg/plot) }\end{array}$} & \multicolumn{2}{|c|}{ Seed yield (kg/plot) } & \multicolumn{2}{|c|}{ Seed yield (q/ha) } & \multicolumn{2}{|c|}{ Harvest Index (\%) } \\
\hline & $\begin{array}{c}\text { Hisar } \\
\text { Sugandh }\end{array}$ & $\begin{array}{c}\text { Hisar } \\
\text { Bhoomit }\end{array}$ & $\begin{array}{c}\text { Hisar } \\
\text { Sugandh }\end{array}$ & $\begin{array}{c}\text { Hisar } \\
\text { Bhoomit }\end{array}$ & $\begin{array}{c}\text { Hisar } \\
\text { Sugandh }\end{array}$ & $\begin{array}{c}\text { Hisar } \\
\text { Bhoomit }\end{array}$ & $\begin{array}{c}\text { Hisar } \\
\text { Sugandh }\end{array}$ & $\begin{array}{c}\text { Hisar } \\
\text { Bhoomit }\end{array}$ & $\begin{array}{c}\text { Hisar } \\
\text { Sugandh }\end{array}$ & $\begin{array}{c}\text { Hisar } \\
\text { Bhoomit }\end{array}$ & $\begin{array}{c}\text { Hisar } \\
\text { Sugandh }\end{array}$ & $\begin{array}{c}\text { Hisar } \\
\text { Bhoomit }\end{array}$ & $\begin{array}{c}\text { Hisar } \\
\text { Sugandh }\end{array}$ & $\begin{array}{c}\text { Hisar } \\
\text { Bhoomit }\end{array}$ \\
\hline T1 & 5.5 & 7 & 33.2 & 47.5 & 152 & 154.7 & 4.23 & 4.473 & 1.393 & 1.406 & 19.33 & 19.51 & 32.92 & 31.42 \\
\hline $\mathbf{T 2}$ & 6 & 7.2 & 36 & 50.8 & 147.3 & 149 & 4.317 & 4.51 & 1.43 & 1.427 & 19.85 & 19.81 & 33.14 & 31.64 \\
\hline T4 & 6.2 & 7.5 & 38.3 & 53.4 & 144 & 146.3 & 4.557 & 4.643 & 1.537 & 1.483 & 21.33 & 20.58 & 33.73 & 31.93 \\
\hline T5 & 6.4 & 7.5 & 41.4 & 54.6 & 142 & 143.3 & 4.57 & 4.71 & 1.543 & 1.509 & 21.42 & 20.95 & 33.77 & 32.04 \\
\hline T6 & 6.2 & 7.4 & 38.5 & 53 & 143 & 145 & 4.607 & 4.693 & 1.48 & 1.475 & 20.55 & 20.47 & 32.13 & 31.43 \\
\hline T7 & 6.3 & 7.4 & 40.5 & 54.2 & 142.3 & 143.7 & 4.547 & 4.68 & 1.527 & 1.491 & 21.2 & 20.7 & 33.59 & 31.87 \\
\hline T8 & 6.6 & 7.6 & 42.8 & 56.4 & 138.7 & 142 & 4.66 & 4.733 & 1.584 & 1.52 & 21.99 & 21.1 & 34 & 32.12 \\
\hline C.D. at 5\% & 0.4 & 0.3 & 3.1 & 4.3 & 2.3 & 3 & 0.129 & 0.066 & 0.067 & 0.034 & 0.94 & 0.47 & 1.03 & 0.35 \\
\hline
\end{tabular}


T8 gave the maximum biological yield for both the varieties. Hisar Bhoomit responded better for biological yield $(4.733 \mathrm{~kg} / \mathrm{plot})$. The reason for the increase in biological yield might be improvement in vegetative growth which was due to the stimulation of cell elongation and increase in plasticity of cell wall (Mohammed, 1975). The results of the present investigation are in accordance with the findings of Singh et al., (2012) in coriander, Verma and Sen (2006) and Moraes and Lopes (1998).

Among different stages of gibberellic acid application, T8 gave the best result for seed yield in both varieties. Hisar Sugandh gave maximum seed yield $(1.584 \mathrm{~kg} / \mathrm{plot})$ due to higher test weight. The cumulative effect of all yield attributes resulted in significant increase in seed yield. Prajapat et al., (2015) in fennel, Krishnaveni et al., (2016) in fenugreek and Haokip et al., (2016) in coriander shows the maximum seed yield with application of $\mathrm{GA}_{3}$.

Among different stages of application, T8 showed the maximum harvest index in both varieties. Maximum harvest index was with Hisar Sugandh (34) due to higher seed yield. The increased harvest index might be attributed to increased seed yield with less biological yield. The beneficial effect of gibberellic acid application on coriander with respect to harvest index is in accordance with the findings of Singh et al., (2012) in coriander, Shah and Samiullah (2006).

Based on the experimental results, it was concluded that application of gibberellic acid improved the growth and yield of coriander seeds. (Seed soaking+ Spray at leaf stage+ Spray at 50\% flowering stage) was the right combination for gibberellic acid application to improve the growth and yield of coriander seed. In case of spray at two stages, Seed soaking + Spray at leaf stage was the right combination to improve the biological yield. Whereas, (Spray at leaf stage + Spray at 50\% flowering) was the right combination to improve the seed yield. The variety Hisar Sugandh performed better for seed yield in present experiment which indicates a good seed yield potential, so there is need to further study on this variety.

\section{Acknowledgements}

The Author would like to acknowledge the financial support given by CCSHAU during the M.Sc. degree programme and would like to express sincere gratitude to Dr. T.P. Malik, Dr. S.K. Tehlan, Principal Scientist, Division of Vegetable Science and Dr. V.K. Batra, Professor and Head, Division of Vegetable Science, CCSHAU-Hisar, Haryana.

\section{References}

Anonymous, 2015. (ICAR-NRCSS). http:// nrcss.res.in.

Donald, C.M. and Hamblin, J., 1976. The biological yield and harvest index of cereals as agronomic and plant breeding criteria. Advances in Agronomy, 28: 361-405.

Gour, R., Naruka, I.S., Singh, P.P., Rathore, S.S. and Shaktawat R.P.S., 2009. Effect of phosphours and plant growth regulators on growth and yield of fenugreek (Trigonellafoenum graecum L.). Journal of Spices and Aromatic Crops, 18(1): 33-36.

Haokip, C.M., Sharangi, A.B., Debbarma, K., Devi, A.K.R. and Karthik, C.S., 2016. Role of plant growth regulators on the growth and yield of coriander (Coriandrum sativum L.). Journal of Crop and Weed, 12(3):33-35.

Krishnaveni, V., Padmalatha, T., Padma, S.S.V., Prasad, N.L.V., 2016. Influence of pinching and plant growth regulators on flowering, yield and economics of 
fenugreek (Trigonellafoenum-graecum L.). Journal of Spices and Aromatic Crops, 25(1): 41-48.

Meena, S.S., Sen, N.L. and Malhotra, S.K., 2006. Influence of sowing date, nitrogen and plant growth regulators on growth and yield of coriander. Journal of Spices and Aromatic Crops, 15(2): 88-92.

Mohammed, H.M., 1975. Effect of $\mathrm{GA}_{3}$, calcium, kinetin and ethylene on growth and cell wall composition of pea epicotyls. Plant Physiology, 56: 622625.

Moraes, D.M. and Lopes, N.F., 1998. Germination and vigour of coriander (Coriandrum sativum L.) seeds treated with plant growth regulators. Revista Brasileira de Sementes, 20(1): 93-99.

Nickel, L. G., 1982.Plant Growth Regulators. Agricultural Uses. Springer-Verlag Berlin-Heidelberg-New York, 173 Seiten, 29 Abb., DM 47, 50.

Panda, M.R., Chatterjee, R., Pariari, A., Chattopadhyay, P.K., Sharangi, A.B. and Alam, K., 2007.Effect of growth regulators on growth, yield and quality of coriander. Indian Journal of Horticulture, 64(3): 369-371.

Prajapat, S.K., Malik, T. P. and Kumar S., 2015.Effect of Gibberellic Acidon Growth and Yield Parameters of Fennel (Foeniculum vulgare Mill.). International Journal of Tropical Agriculture, 33(4):3911-3916.

Shah, S.H. and Samiullah, 2006. Effect of phytohormones on growth and yield of black cumin (Nigella sativa L.). Indian Journal of Plant Physiology, 11: 217221.

Singh, D., Singh, P. P., Naruka, I. S. and Shaktawat, R. P. S. 2012. Effect of plant growth regulators on growth and yield of coriander. Indian Journal of Horticulture, 69: 91-93.

Singh, P., Mor, V.S., Khan, M., Kumar, S., 2017, Effect of Foliage Cuttings on Seed Yield and Quality of Coriander (Coriandrum sativum L.). Advances in Research 10(4): 1-9.

Verma, P. and Sen. N.L., 2006.Effect of plant growth regulators on vegetative growth and seed yield of coriander cv. RCr435. Journal of Spices and Aromatic Crops, 15(2): 118-122.

\section{How to cite this article:}

Sachin Kumar, T.P. Malik and Tehlan, S.K. 2018. Effect of Gibberellic Acid on Growth and Seed Yield of Coriander (Coriandrum sativum L.). Int.J.Curr.Microbiol.App.Sci. 7(09): 25582566. doi: https://doi.org/10.20546/ijcmas.2018.709.318 